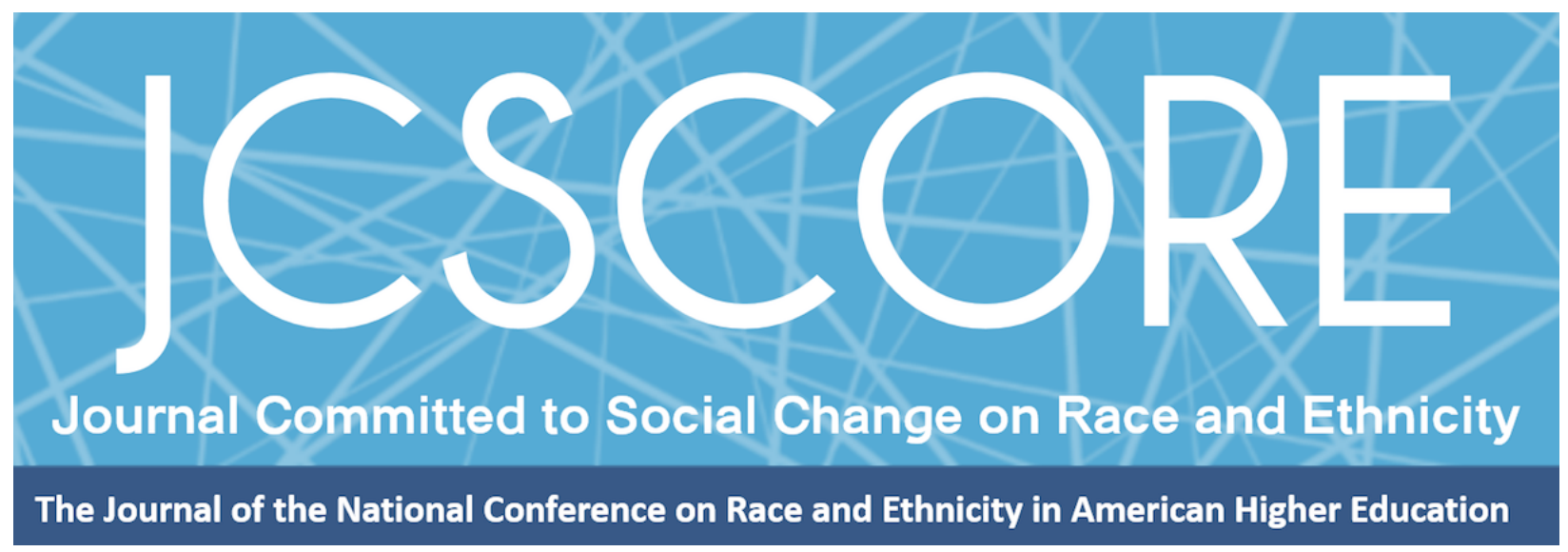

\title{
"JUST MY BEING HERE IS SELF-ADVOCACY": EXPLORING THE SELF-ADVOCACY EXPERIENCES OF DISABLED GRADUATE STUDENTS OF COLOR
}

Julia Rose Karpicz

University of California, Los Angeles

Journal Committed to Social Change on Race and Ethnicity

Volume 6, Issue 1 | 2020

Copyright and Open Access

(C) 2020 Julia Rose Karpicz

\section{(c)}

This work is licensed under a Creative Commons Attribution-NonCommercial-ShareAlike 4.0 International License. Permission of the authors is required for distribution and for all derivative works, including compilations and translations. Quoting small sections of text is allowed as long as there is appropriate attribution and the article is used for non-commercial purposes.

The Journal Committed to Social Change on Race and Ethnicity (ISSN 2642-2387) is published by the National Conference on Race and Ethnicity (NCORE), a production of the University of Oklahoma, in partnership with the University of Oklahoma Libraries. 


\title{
"Just My Being Here is Self-Advocacy": Exploring the Self-Advocacy Experiences of Disabled Graduate Students of Color
}

\author{
Julia Rose Karpicz \\ University of California, Los Angeles
}

\begin{abstract}
Self-advocacy is emphasized as a critical practice for improving the retention and increasing the success of disabled students. In higher education, disability service offices and academic researchers jointly shape the conversation around what comprises effective self-advocacy. Students who are not engaging in these prescribed strategies are then framed as underprepared and/or lacking the skills required to self-advocate effectively. Unexamined within this discourse are how identity, power, and environment shape students' self-advocacy as well as the ways students engage in self-advocacy outside of normative accommodation structures. This study intervenes by examining the extent to which dominant scholarly and practitioner understandings of self-advocacy align, resonate, and/or diverge from the lived experiences of self-advocacy among disabled graduate students of color. By centering the voices of multiply marginalized students, this study raises questions about what may be obscured when scholars rely only on academic definitions of self-advocacy in the design, framing, and analysis of their research.
\end{abstract}

Self-advocacy is considered a critical practice for improving the retention and increasing the success of disabled students (Daly-Cano et al., 2015). In higher education, self-advocacy research and resources emphasize certain strategies, such as self-disclosure and compromise, as effective methods of self-advocacy (Getzel \& Thoma, 2008; McCarthy, 2007). These resources often frame students who are not engaging in strategies as underprepared, irresponsible, or otherwise lacking the skills required to effectively self-advocate (Stamp et al., 2014). Underexamined within this discourse is how identity, power, and environment shape, facilitate, and constrain disabled students' self-advocacy. 
Journal Committed to Social Change on Race and Ethnicity | Volume 6, Issue 1 | 2020

By focusing on self-advocacy as an individual practice, scholars and practitioners obscure how institutional contexts and interactions produce inaccessible spaces and create the impetus for student self-advocacy as a strategy for redressing a lack of access. For example, Fleming et al. (2017) discuss how, even when students have overtly negative interactions with faculty or staff around accessibility, "the response is often that students need [stronger] self-advocacy and self-determination skills ... implying that negative interactions and denied accommodations are the students' problem - not the university's" (p. 322). These narratives of self-advocacy as an individual practice offer limited critiques of the conditions that make self-advocacy necessary, as well as the structural and attitudinal barriers that coalesce to shape whether student self-advocacy will be effective. In particular, by failing to engage with how traditional self-advocacy is influenced by intersecting forms of marginalization (e.g., ableism, racism), the narrative around what self-advocacy is, and can do, has been over-simplified. Further, by relying on self-advocacy frameworks that were originally developed to explain the experiences of secondary students with disabilities (Gelbar et al., 2019), the complexities of self-advocacy for students in post-secondary education are under-theorized.

This study expands on traditional conversations around disabled student selfadvocacy by centering the experiential knowledge of disabled graduate students of color. More specifically, this study explores and is guided by the following questions:

1. How do disabled graduate students of color narrate their experiences of selfadvocacy in relation to prominent models of self-advocacy? 
Journal Committed to Social Change on Race and Ethnicity | Volume 6, Issue 1 | 2020

2. How are their self-advocacy experiences and strategies shaped by their experiences as disabled students of color within higher education?

\section{Literature Review}

Self-advocacy emerged as a central commitment of disabled organizers and nondisabled advocates towards the end of the twentieth century in the United States, Canada, Sweden, and the United Kingdom (Buchanan \& Walmsley, 2006). The earliest definitions of self-advocacy in the empirical literature reflect its origins as a disability-led, political and social movement that sought to empower people with learning and developmental disabilities to "assert their legal rights and challenge the stereotyped view that persons with [disabilities] cannot speak for themselves" (Sievert et al., 1988, p. 299). Over time, self-advocacy was co-opted by a range of service providers who "jump[ed] on the bandwagon of self-advocacy" and sought to normalize certain practices as constituting effective self-advocacy (Aspis, 1997, p. 652). For example, in higher education, disability service offices and academic researchers jointly shape the conversation around self-advocacy by centering certain strategies - such as selfdisclosure and requesting accommodations - as effective self-advocacy approaches. These recommended practices fit within a provider model, where self-advocacy is presented as primarily working within the prescribed institutional structures to pursue formal support (Dolmage, 2017).

Research on self-advocacy is frequently situated within a deficit framework (Dinishak, 2016), which argues that students frequently lack self-advocacy skills and require differentiated and remedial coaching by disability services professionals in order to be successful (Stamp et al., 2014; Vaccaro \& Kimball, 2017). For example, Ju et al. 
Journal Committed to Social Change on Race and Ethnicity | Volume 6, Issue 1 | 2020

(2017) present disabled students as often "underprepared in self-advocacy ... lack[ing] effective communication skills to interact with professors or disability service staff to acquire or use accommodations" (p. 181). The literature advances the assumption that prescribed self-advocacy skills, if developed, will be effective for all disabled students (Daly-Cano et al., 2015; Test et al., 2005). It reproduces disapproving narratives about students who do not engage in traditionally prescribed self-advocacy strategies, such as requesting formal accommodations (Getzel \& Thoma, 2008; McCarthy, 2007), labeling these students as underprepared, irresponsible, or lacking a certain skillset. Selfadvocacy research does not consider how identity, power, and environment intersect to influence students' self-advocacy or how students may be engaging in self-advocacy in unique ways that are not easily legible under current models of self-advocacy.

This lack of attention to identity and power is particularly visible in the lack of engagement within self-advocacy literature around racial identity. While students of color are often represented within the sample of students who have participated in selfadvocacy research (Getzel \& Thoma, 2008), this literature does not specifically address the influences of racial identity on students' experience with self-advocacy in education (Roberts et al., 2016; Walker \& Test, 2011). Though their primary focus is not on selfadvocacy, the handful of studies that specifically explore the postsecondary experiences of disabled students of color document how racial bias in faculty interactions can render students' disclosures of disability ineffective when attempting to secure accommodations (Petersen, 2009) and prompt a "heightened level of stress" around their identity (Banks \& Gibson, 2016, p. 79). These studies suggest that the lack of attention to how racial identity informs students' experiences with self-advocacy 
Journal Committed to Social Change on Race and Ethnicity | Volume 6, Issue 1 | 2020

represents a consequential gap in the academic literature on self-advocacy. I sought to address this absence by centering the voices and experiential knowledge of disabled graduate students of color, "troubl[ing] singular notions of identity" (Annamma et al., 2013, p. 11) and pushing for multidimensional representations of students' selfadvocacy experiences.

\section{Theoretical Framework}

In seeking to understand how racial and disability identities intersect and inform graduate students' experiences with self-advocacy, this study is grounded in a Disability Studies Critical Race Theory (DisCrit) framework. As a conceptual framework, DisCrit "theorizes about the ways in which race, racism, dis/ability and ableism are built into the interactions, procedures, discourses, and institutions of education, which affect students of color with dis/abilities qualitatively differently than white students with dis/abilities" (Annamma et al., 2013, p. 7). DisCrit challenges constructions of both Whiteness and ability as "the normative cultural standards" (Annamma et al., 2013, p. 12) against which difference becomes deficit. The framework builds upon a limited, but significant, genealogy of scholarship that has mapped the ways racism and ableism intersect; particularly how ableist logics and rhetoric are used to justify the marginalization of people of color (Annamma et al., 2018; Bell, 2011). DisCrit purposefully weaves together Disability Studies and Critical Race Theory (CRT) as theoretical frameworks that have independently critiqued racism and ableism as endemic to society, but which have historically resisted "joint thinking" around racism and ableism as "interconnected and collusive" (Annamma et al., 2013, p. 6). Specifically, DisCrit builds from CRT's 
Journal Committed to Social Change on Race and Ethnicity | Volume 6, Issue 1 | 2020

critique of racism as endemic (Ladson-Billings, 1998) to theorize how hegemonic Whiteness shapes dominant understandings of disability (Annamma et al., 2013).

As self-advocacy addresses inaccessibility within the classroom, but takes place in interactions between students and faculty, I used a social-relational model of disability to explore how disability is constituted through interaction and environment in higher education. The social model of disability considers how spaces are built in ways that enable or disable individuals, while the relational model of disability focuses on how disability emerges through social interaction (Evans et al., 2017).

\section{Research Methods}

This qualitative study used a constructivist paradigm to explore the multiplicity of students' lived experiences with self-advocacy (Creswell \& Creswell, 2018). A constructivist approach recognizes reality as socially constructed and seeks to understand how individuals interpret and make meaning of their lived experience (Bhattacharya, 2017). By insisting on the particularity of experiences of disabled students of color, this project assumed that there are multiple ways of understanding and experiencing self-advocacy, and I encouraged participants to reflect on these nuances throughout the interview.

\section{Participant Selection and Recruitment}

A purposeful sampling procedure was used to recruit seven students of color who identify as having one or more disabilities and who are currently enrolled in a U.S. graduate program or who have been enrolled in a U.S. graduate program within the past year (Creswell \& Creswell, 2018). The limited literature on disabled graduate students offers evidence that their unique positions at the intersection of student, 
Journal Committed to Social Change on Race and Ethnicity | Volume 6, Issue 1 | 2020

teaching, and staff positions can facilitate dynamic understandings of ableism in higher education (Damiani \& Harbour, 2015). I focused on disabled graduate students of color to understand how their experiential knowledge about self-advocacy evolved as they moved through undergraduate and graduate environments.

The project was open to graduate students from any U.S. higher education institution to capture how students' self-advocacy was shaped by a variety of institutional environments (e.g., size, location, public, private). In order to gather "a range of differences and experiences with disability in the university setting" (Damiani \& Harbour, 2015, p. 403), I opened the study to graduate students of color who selfidentified as disabled. They did not need a formal diagnosis and did not need to have officially worked with disability services on campus to participate in the study. I used this criterion intentionally to be inclusive of students who have experienced barriers in accessing a disability diagnosis and/or official accommodations (Blanchett, 2010). Additionally, as many disabled students do not formally register with their campus disability services offices (Dong \& Lucas, 2016), I was interested in student narratives about how self-advocacy unfolds outside of a formal accommodation structure. Participants were recruited using word-of-mouth, flyers, email, and social media. Confidentiality was ensured by using individual and institutional pseudonyms. Participants received a $\$ 25$ gift card for their participation.

\section{Participants}


I conducted interviews with seven participants between July 2018 and March 2019. These participants were primarily Black and Latinx ${ }^{1}$ and had a broad range of disabilities. They had been enrolled in both public and private institutions across the country. Specific demographic information is included in Table 1.

Table 1: Participant Summary

\begin{tabular}{|c|c|c|c|}
\hline Name & Disability & $\begin{array}{c}\text { Race I } \\
\text { Ethnicity }\end{array}$ & Grad. Institution(s) \\
\hline Maria & Blind, ADHD, Chronic Health & Latina & Private, East Coast \\
\hline Ariel & $\begin{array}{c}\text { Learning Disability, Mental } \\
\text { Health, Chronic Health }\end{array}$ & Latinx & Public, West Coast \\
\hline Gene & Blind & Black & Public, Southern \\
\hline Paula & Chronic Health & Latina & Public, West Coast \\
\hline Sam & Learning Disability & Black, mixed & Private, East Coast \\
\hline Naomi & Mental Health, Chronic & Mixed race & Private, West Coast \\
\hline Evette & Blind, Mental Health & Black & Public, Midwest (1 \\
\hline
\end{tabular}

\section{Data Collection}

I used two, hour-long semi-structured interviews with each of the participants as a space for disabled graduate students of color to narrate their understanding and experiences with self-advocacy in higher education. For both interviews, participants were provided with the interview questions in advance and allowed to review their transcripts to check for accuracy and to offer clarification (Bhattacharya, 2017). Interviews were conducted remotely and in-person.

${ }^{1}$ I use Latinx as a gender-inclusive term to collectively refer to the three students of Latin American descent who participated in this study (Salinas \& Lozano, 2019). When referring to these students individually, I include how participants self-identified. 
Journal Committed to Social Change on Race and Ethnicity | Volume 6, Issue 1 | 2020

The first interview explored students' educational background, their experiences with self-advocacy in higher education, how students made meaning of their experiences with self-advocacy, and how they understood and navigated self-advocacy as disabled graduate students of color. The questions in the first interview were informed by the first and fourth tenets of DisCrit (Annamma et al., 2013). Specifically, by opening the interview with grounding, background questions about experiences with education, access, race, and disability, the interview focused in on the first tenet - how the forces of racism and ableism have circulated in students' educational experiences before shifting to discuss how these experiences then influenced their practice of selfadvocacy. By asking participants to describe what self-advocacy has meant and looked like in their experiences, the interview similarly incorporated the fourth tenet of DisCrit, which emphasizes privileging the voices of marginalized populations.

The second interview used artifact elicitation to prompt reflection and discussion about how scholars have framed self-advocacy and how this aligned with the students' own experiences of self-advocacy. Prior to the second interview, students were asked to review the Test et al. (2005) framework of self-advocacy, which was then used to elicit participant reflection on the components of self-advocacy they felt were relevant to the experiences of disabled students of color. I selected the Test et al. (2005) framework for the elicitation (Bhattacharya, 2017) because it synthesizes over two decades of academic research on self-advocacy and, as such, functions as a compilation of "master narratives" about self-advocacy (Annamma et al., 2013, p. 14) while also avoiding academic jargon and being visually well-organized. The second interview protocol expanded on DisCrit's fourth tenet by placing participants directly in 
Journal Committed to Social Change on Race and Ethnicity | Volume 6, Issue 1 | 2020

dialogue with researcher narratives about what self-advocacy comprises (Annamma et al., 2013). The self-advocacy framework, reflection questions, and the prompt for the framework activity were provided and reviewed at the end of the first interview in order to answer questions and ensure understanding. All interview materials were made available to students in digital, print, or tactile format, as requested.

\section{Data Analysis}

Interview transcripts were analyzed using an open coding process (Saldaña, 2009) in which I explored the "connectedness of the data," pulling out and examining "the short stories embedded within the larger narrative" of each transcript (Bazeley, 2013, p. 113). I used the patchwork quilt metaphor to visualize my data during this initial analysis, an approach used "to present participant data as both unique and part of a larger whole" (Koelsch, 2012, p. 823). I used this analytic method to organize excerpts into preliminary themes (e.g., healthcare) that I then examined for similarities and differences. For example, in grouping excerpts about self-advocacy and healthcare, I identified how participants with chronic health conditions were having similar types of racialized encounters with providers, while still observing how these experiences varied based on participants' particular disabilities. I used axial coding to organize these initial themes into broader categories (e.g., impacts of off-campus self-advocacy), working to understand how participants' stories related within and across themes (Saldaña, 2009). Throughout the project, I engaged in peer debriefing with two colleagues in the disability services field to refine my analysis (Creswell \& Creswell, 2018). 
Journal Committed to Social Change on Race and Ethnicity | Volume 6, Issue 1 | 2020

\section{Researcher Positionality}

This study grew from reflections on my experience as a disability services professional working with disabled graduate students of color. Although the need to cultivate student self-advocacy skills saturated my professional resources, the guidelines often felt formulaic and inadequate in addressing the racial microaggressions and coded language that I saw students encountering in response to their self-advocacy efforts. In approaching these conversations, I drew largely from my experiences navigating racism as a Black woman with mental illness in predominantly white mental health spaces. Through these conversations, I realized that, while I often do not engage in self-disclosure, I have been strategic in navigating postsecondary spaces in ways that are self-protective. These reflections prompted me to engage in problem-posing around self-advocacy, race, and disability. While my positionality as a disabled graduate student of color and former disability services practitioner opened shared space in my interviews, the participants in this study brought knowledge to this work that exceeded my own - detailing lived experiences with (in)accessibility, bias, and strategizing that has shaped not only how I understand this research and its place within literature, but also my identity and experiences.

\section{Limitations}

By opening recruitment to students with diverse types of disability, it is beyond the scope of this project to explore the nuances of self-advocacy for students with one type of disability in great depth. Additionally, the participants in this study all identified as disabled, with "a political understanding about that lived experience;" therefore, the perspectives of disabled students of color who have "lived experience of being disabled 
Journal Committed to Social Change on Race and Ethnicity | Volume 6, Issue 1 | 2020

[but] may not talk about ableism, discrimination or even call themselves 'disabled"' (Mingus, 2010, para. 4) are not present in this data. These limitations represent important areas for further critical theorizing, research, and dialogue. Nevertheless, the voices in this work contribute substantively to the practitioner and scholarly discourse around self-advocacy, offering rich and complex narratives about navigating higher education as a disabled student of color.

\section{Findings}

In placing participants' narratives in dialogue with existing literature on selfadvocacy, there were three areas that emerged from the data as distinctive: (1) how participants learned self-advocacy, (2) their experiences with shifting institutional support in graduate school, and (3) what comprised participants' self-advocacy strategies.

\section{Learning About Self-Advocacy}

The academic literature on self-advocacy in postsecondary environments often frames the cultivation of student self-advocacy as a key role of postsecondary disability services professionals (McCarthy, 2007). None of the participants in the study discussed having formal, substantive conversations with their campus disability services office, or any other campus personnel, about self-advocacy at any point in the undergraduate or graduate education. Most students described their disability services offices as providing general information, for example Ariel stated, "teaching me what I would need to do to get the accommodation more so than, like, self-advocacy". Gene pointedly critiqued how disability services offices are positioned in the conversation about self-advocacy in higher education, noting that, 
Journal Committed to Social Change on Race and Ethnicity | Volume 6, Issue 1 | 2020

I have not seen, nor have I heard of, any disability services office personnel that has 'adequately' shown people how to be self-advocates; they might say "you should advocate on your behalf" but that's also like me saying, "hey, you should go out there and hit a twenty-point jump shot."

Gene emphasized the absence of meaningful support around self-advocacy within disability services, unsettling the narrative of disability services professionals as the providers of skills coaching (Stamp et al., 2014; Vaccaro \& Kimball, 2017). Rather than learning about self-advocacy from campus staff, students expanded their self-advocacy knowledge by connecting with other disabled and non-disabled students of color oncampus and in online communities.

Participants also discussed observing and learning about self-advocacy outside of higher education, particularly in interactions with family and healthcare providers. For many students, self-advocacy was directly taught and modeled by family members and caregivers. Four participants described learning how to self-advocate by observing how caregivers advocated for themselves and navigated marginalization. For example, Gene and Evette both discussed learning self-advocacy as children from watching their parents' local organizing and civil rights activism. Evette reflected, "I'm very fortunate that my parents both have a disability and they, whether they call it advocacy or not, they had to be their own champion." By contrast, other participants developed advocacy strategies in response to challenges in their home environment. For example, Sam's family fought to keep him in a mainstream classroom after his K-12 school misdiagnosed him, concerned that his being in a segregated, special education would make him more vulnerable to forms of school discipline leading to incarceration (Annamma et al., 2018). As Sam entered college and sought an accurate diagnosis for accommodations, he developed "a dual advocacy" across academic and family spaces 
Journal Committed to Social Change on Race and Ethnicity | Volume 6, Issue 1 | 2020

- the latter involving "being able to combat sometimes your own family who might not understand a lot of what you're going through."

In addition to learning about self-advocacy through family, participants with chronic health conditions also spoke about hostile interactions in clinical settings, particularly in regard to misdiagnosis, as contributing to their self-advocacy knowledge and awareness. Naomi, who had to switch providers and hospitals after being refused treatment for her chronic pain, noted that "women already get dismissed all the time; if you're a person of color you get dismissed even more." Naomi and Paula also pointed to bias around age as impacting their experiences in these clinical environments. Paula recalled being "misguided" by her doctor, who misdiagnosed her condition and "would throw me away saying, "you're too young"' for the procedure that would have confirmed she had been misdiagnosed. Participants credited these external learning experiences as contributing to their current "empowerment and advocacy" as students.

\section{Shifting Institutional Support in Graduate School}

Participants described how self-advocacy became more salient in graduate school, as they navigated key shifts in the degree and quality of institutional support available to them around access and accommodations. Several participants had shifted from larger institutions to small, graduate institutions, where the disability services office was limited in the available resources and office capacity. Even at larger institutions, graduate accommodations were often coordinated by administrators within the program, who frequently lacked experience addressing disability-related access needs. For example, in Evette's graduate program, "the summer program coordinator also had a dual role of dealing with accessibility," and in Ariel's department, "you have to discuss 
Journal Committed to Social Change on Race and Ethnicity | Volume 6, Issue 1 | 2020

[accommodations] with the head of the department, apparently, or [the department's] office of student services, about what they can do if you need modifications."

Several participants discussed having to engage in disclosure and self-advocacy more frequently as graduate students due to changes in department and institutional resources at the graduate-level. Coming from an undergraduate institution that provided evaluations on-campus, Sam discussed being surprised by the lack of institutional resources for getting updated disability documentation in graduate school. Without access to formal documentation, Sam realized, "I was going to have to do some explaining; it wasn't going to be this clean, easy, dry process that they claim in a lot of the disability offices."

Participants observed that they often had to engage in greater degrees of selfdisclosure than their white, disabled peers before they were able to get their access needs met. For example, Maria described an experience in a graduate course where the faculty member worked "proactively" and informally to support the access needs of two white, disabled students in the course, but told her and another disabled student of color in the course that they "need to go to disability services" to request accommodations. When Maria raised this differential treatment as a concern, the faculty member responded with the reasoning, "I don't know what you need culturally." Maria noted that, by requiring the students of color to work with disability services, they ended up "having to deal with a cost barrier [as well as] . . . a time barrier."

\section{Self-Advocacy Strategies: Non-Disclosure}

Despite the increased pressure to self-disclose to a greater range of people, participants also described veering away from traditional practices of disclosure as a 
Journal Committed to Social Change on Race and Ethnicity | Volume 6, Issue 1 | 2020

form of self-advocacy during their time as graduate students. Several students described choosing not to disclose certain information as a self-advocacy strategy in graduate school. For example, although she had always been encouraged to disclose her disability information, Maria described learning to "not provide as much information." As she explained, "it's not very advantageous... they [instructors] don't really, explicitly listen to you; they don't read that stuff." Instead, Maria found that faculty often made assumptions about her access needs based on their limited understanding of her disability. They were also inflexible when her access needs shifted over time.

Another participant, Ariel, avoided disclosing her disability to avoid putting faculty in a position where they could dis/affirm her disability. She shared,

I think for me right now, self-advocacy is just, like if I realize that I can turn something in late, I'Il just turn it in when I can, and then if they want to speak about it, they can speak to me about it ... I think minimizing the time that I have to be interacting with professors in terms of this relationship of [them] always having to validate this identity.

Ariel learned over time that avoiding interactions where faculty could be affirming or dismissive of her chronic health condition and access needs was a more sustainable practice than constantly being vulnerable to faculty judgment on the validity of her experience. Naomi similarly described developing the ability to read environments to determine whether it was safe to disclose disability information or if it was better to "protect yourself." Several participants discussed race and racism as directly informing their decisions around disclosure. Sam explained, "[l]f I choose to disclose or not to disclose, race is always something that filters through that; it helps me make that decision." When environments appeared to be hostile, resistant, or marginalizing, 
Journal Committed to Social Change on Race and Ethnicity | Volume 6, Issue 1 | 2020

students felt that disclosing their disability status would be neither beneficial, nor necessarily safe.

\section{Self-Advocacy Strategies: Deciding to Leave}

There were three students who had left their most recent graduate program due to persistent access barriers. Their departure decisions came after persistent attempts at communicating access barriers to faculty and staff who resisted making substantive changes to the delivery of course content. For one participant, Gene, whose institution would not provide accessible exam materials, he countered the institution's narrative that he had not passed his qualifying exam by stating: "[T]hey said I failed my exam; I said 'I didn't fail my exam, I quit doing my exam.' After years of meetings with faculty and administrators and filing complaints against the department, he decided to leave his program to pursue work that was more meaningful to him.

Sam similarly described "fighting for accommodations, tooth and nail," but not having faculty or the institution's disability services office address persistent barriers around the pace of the coursework. Like Gene, Sam determined that his program was not serving his learning and left to pursue other opportunities. Sam described the decision to leave as empowering:

[T] he fact that I could advocate for myself made me feel powerful ... but also the fact that I could keep up in a system designed for them, made for them, and not for me, and not for any of my experiences[,] that I still kept up, I still was passing, until I made the choice to leave; I survived that shit.

Sam describes how just by existing and persisting in an academic space that was not designed for his participation or success, he was engaging in self-advocacy. Ariel similarly noted, "just my being here is self-advocacy." 
Journal Committed to Social Change on Race and Ethnicity | Volume 6, Issue 1 | 2020

On an individual level, these moments of agency can be understood as forms of advocacy: participants recognized what they needed and took definitive steps to pursue a space that met their needs. However, on a systemic level, these moments reveal the precarity in relying on students to compel change within institutions that have been historically resistant to providing access. Participants reflected on this one-sidedness, noting the emphasis on students as self-advocates belies the central role of faculty and staff in creating (in)accessible environments. As Paula noted, "I can just scream my lungs out demanding for accommodation, but if the other parties are not willing to listen ... what are the mechanisms that facilitate the communication?"

\section{Discussion}

The research on self-advocacy frequently argues that disabled students need better self-advocacy skills in order to be successful (Ju et al., 2017; Stamp et al., 2014) and emphasizes traditional strategies, such as disability disclosure and requesting formal accommodations (Getzel \& Thoma, 2008; McCarthy, 2007; Vaccaro et al., 2019). Whereas students are often portrayed in the literature in a deficit-framework, as lacking necessary self-advocacy skills, the participants in this study expanded upon and complicated core aspects of traditional paradigms of self-advocacy in higher education. For example, participants expanded on existing scholarship about how postsecondary students learn to self-advocate, particularly literature examining how families provide supportive instruction and experiences around disability-related self-advocacy for their children (Daly-Cano et al., 2015). Participants observed how family members navigated racial and sometimes disability-related marginalization, their advocacy modeling that "lying down was not an option". 
Journal Committed to Social Change on Race and Ethnicity | Volume 6, Issue 1 | 2020

Participants also drew attention to the need for disabled students of color to understand how racism and ableism, as intersecting forms of oppression, "affect disability or the way you obtain accommodations or combat access barriers or do your daily life routine." Specifically, participants discussed the racialized barriers they experienced navigating healthcare and educational spaces, including the differential treatment they experienced around accommodation and faculty support, as evidencing the ways in which ableism and racism circulate interdependently in students' lived experiences (Annamma et al., 2013).

The lack of literature centering the experiences of disabled graduate students (Carter et al., 2017), specifically disabled graduate students of color, obscures their lived experiences within higher education and the rich complexities of their student selfadvocacy. Self-advocacy research and resources largely focus on undergraduates, but borrow heavily from theoretical frameworks of self-advocacy that were developed on the experiences of high school students (Gelbar et al., 2019). This study calls attention to how researchers have overlooked the experiences and theoretical contributions that graduate students can bring to the conversation around self-advocacy. In particular, there is limited engagement with how experiences of self-advocacy shift over time and across educational levels. As Carter et al. (2017) argue, graduate students, must navigate a complex web of power. The connections among academic norms and rituals; institutional policies; hierarchies of race, nation, class, gender, and sexuality; and the corporeality of our bodies present circumstances that are distinct from the struggles of disabled undergraduate students or disabled faculty members. (p. 96)

Participants in this study spoke to these complex webs, emphasizing how structural changes in the way support was provided, the varying degrees of institutional 
Journal Committed to Social Change on Race and Ethnicity | Volume 6, Issue 1 | 2020

resources, and faculty bias increased the pressure to engage in self-disclosure as graduate students.

The ways in which students learned to navigate diverse postsecondary environments echoes existing scholarship on how disabled graduate students develop complex strategies regarding self-accommodation and disclosure, nuanced ways of deciding "when and where to talk about disability" (Damiani \& Harbour, 2015, p. 409). Specifically, participants described developing a range of subversive and selfpreserving practices in response to the ways multiple marginalization (con)strained their self-advocacy. These practices, such as non-disclosure and departure, challenge how direct communication about disability and access barriers is frequently framed by scholars and practitioners as the foundational component of self-advocacy (Test et al., 2005; Vaccaro et al., 2019).

In considering how non-disclosure and departure function as forms of selfadvocacy, I draw from theoretical scholarship on refusal as a strategy through which marginalized communities navigate power structures that demand disclosure, visibility, and vulnerability (Campt, 2019; Tuck \& Yang, 2014). In this instance, prescribed selfadvocacy strategies in higher education hinge on students' disclosure of disability information, as Maria described, "I've always been taught the more information you provide, potentially the more helpful it could be." This framing of disclosure as necessary for equal access reflects institutions' insistence on their "unquestioned right to know" students' disability information (Tuck \& Yang, 2014, p. 816). However, several participants observed how they were being pushed to disclose a greater degree of disability information than their White peers in order to justify their access requests with 
Journal Committed to Social Change on Race and Ethnicity | Volume 6, Issue 1 | 2020

faculty. Moreover, participants described even this heightened disclosure being met with resistance and persistent inaccessibility, revealing this emphasis on student disclosure to be a hollow and frustrating exercise for disabled students of color.

In response, several participants described learning when to push back on the system through non-disclosure and departure, practices that reflect a "refusal to recognize a system that renders you fundamentally illegible and unintelligible" (Campt, 2019, p. 83). For several students faced with environments that systematically dismissed their advocacy efforts, refusal to engage, or to continue participating as prescribed, resulted in empowerment and self-preservation. I argue that these strategies of non-disclosure and departure can be understood as practices of refusal and that refusal itself can constitute a form of self-advocacy. By engaging in refusal as a form of self-advocacy, disabled graduate students of color "turn[ed] the gaze back on power" (Tuck \& Yang, 2014, p. 817), spotlighting the persistent failures of institutional systems that rely solely on individual accommodations to create meaningful access for disabled students.

By centering traditional frameworks of self-advocacy, disability services offices and academic researchers have maintained a paradigm around self-advocacy as individual disclosure that does not adequately capture how marginalization shapes and constrains self-advocacy for disabled students of color. These narratives point to the need for disability services offices to expand and complicate self-advocacy resources. For example, disability-related supports can vary widely based on institutional type, resources, and location (Evans et al., 2017; Kimball et al., 2016), and several participants spoke to the extensive "investigative work" they engaged in to understand 
Journal Committed to Social Change on Race and Ethnicity | Volume 6, Issue 1 | 2020

resources they were eligible to use (e.g., evaluations, tutoring). Institutions should make information about disability-related resources transparent and accessible to incoming and current students.

Additionally, and as expressed by Noemi, practitioners should expand their advocacy work to address access barriers that emerge as ableism intersects with other forms of structural oppression, deepening their understanding of "how the different intersections of [students'] identities are going to affect the help that [they're] receiving and the help that [they're] going to have to advocate for". As part of this effort, disability services offices should expand their partnerships with diversity and multicultural offices on-campus (Scott, 2019). In addition, practitioners should develop resources that recognize student self-advocacy as a collective practice and directly address the role of faculty and staff in facilitating it. For example, they should discuss how to be responsive to student self-advocacy, how bias can shape these responses, and how faculty and staff can proactively design accessible spaces to reduce the pressure on students to disclose.

\section{Conclusion}

This study explores the extent to which dominant scholarly and practitioner understandings of self-advocacy align, resonate, and/or diverge from the lived experiences of self-advocacy among students experiencing intersecting forms of marginalization. This study builds on the work of activists and academics who have used disability justice to critique how dominant ways of creating knowledge about disability too often minimize the knowledge and experiences of disabled people of color. Specifically, this study contributes to a dialogue around what is obscured when scholars 
Journal Committed to Social Change on Race and Ethnicity | Volume 6, Issue 1 | 2020

and practitioners rely only on academic definitions of self-advocacy in the design and framing of self-advocacy research and resources.

Centering disabled students of color in the conversation on self-advocacy expands current definitions of self-advocacy within the literature, demonstrating how self-advocacy is fluid and context-specific, and challenging the framing of nondisclosure as reflecting a lack of self-advocacy skills. It points to the need for more critical understandings of self-advocacy, given the way racism and ableism mutually operate to constrain what is possible for disabled students of color through selfadvocacy. These critical understandings can move institutions closer to what Mingus (2018) refers to as "disability justice space," campus spaces that can hold "disability in a complex and nuanced way" (para. 6). They can help institutions finally recognize the depth of systems knowledge that disabled graduate students of color have built over the course of their educational journeys. 
Journal Committed to Social Change on Race and Ethnicity | Volume 6, Issue 1 | 2020

\section{References}

Annamma, S.A., Connor, D., \& Ferri, B. (2013). Dis/ability critical race studies (DisCrit): theorizing at the intersections of race and dis/ability. Race Ethnicity and Education, 16(1), 1-31. https://doi.org/10.1080/13613324.2012.730511

Annamma, S.A., Ferri, B.A., \& Connor, D.J. (2018). Disability critical race theory: Exploring the intersectional lineage, emergence, and potential futures of DisCrit in education. Review of Research in Education, 42(1), 46-71. https://doi.org/10.3102/0091732X18759041

Aspis, S. (1997). Self-advocacy for people with learning difficulties: Does it have a future? Disability \& Society, 12(4), 647-654. https://doi.org/10.1080/09687599727182

Banks, J., \& Gibson, S. (2016). The voices of African American male students with disabilities attending historically black universities. Journal of African American Males in Education, 7(1), 70-86.

Bazeley, P. (2013). Qualitative data analysis: Practical strategies. Sage Publications.

Bhattacharya, K. (2017). Fundamentals of qualitative research: A practical guide. Routledge.

Bell, C. (2011). Introduction: Doing representational detective work. In C. Bell (Ed.), Blackness and disability (pp. 1-7). Michigan State University Press.

Blanchett, W.J. (2010). Telling it like it is: The role of race, class, \& culture in the perpetuation of learning disability as a privileged category for the white middle class. Disability Studies Quarterly, 30(2). http://dx.doi.org/10.18061/dsq.v30i2.1233

Buchanan, I., \& Walmsley, J. (2006). Self-advocacy in historical perspective. British Journal of Learning Disabilities, 34(3), 133-138. https://doi.org/10.1111/j.14683156.2006.00410.x

Campt, T.M. (2019). Black visuality and the practice of refusal. Women \& Performance: A Journal of Feminist Theory, 29(1), 79-87. https://doi.org/10.1080/0740770X.2019.1573625

Carter, A., Catania, T., Schmitt, S., \& Swenson, A. (2017). Bodyminds like ours: An autoethnographic analysis of graduate school, disability, and the politics of disclosure. In S.L. Kerschbaum, L.T. Eisenman, \& J.M. Jones (Eds.), Negotiating disability: Disclosure and higher education (pp. 95-113). University of Michigan Press.

Creswell, J.W., \& Creswell, J.D. (2018). Research design: Qualitative, quantitative, and mixed methods approaches. Sage Publications.

Daly-Cano, M., Vaccaro, A., \& Newman, B.M. (2015). College student narratives about learning and using self-advocacy skills. Journal of Postsecondary Education and Disability, 28(2), 209-223.

Damiani, M.L. \& Harbour, W.S. (2015). Being the wizard behind the curtain: Teaching experiences of graduate teaching assistants with disabilities at U.S. universities. Innovative Higher Education, 40(5), 399-413. https://doi.org/10.1007/s10755015-9326-7

Dinishak, J. (2016). The deficit view and its critics. Disability Studies Quarterly, 36(4). http://dx.doi.org/10.18061/dsq.v36i4.5236

Dolmage, J. (2017). Academic ableism: Disability and higher education. University of Michigan Press. 
Journal Committed to Social Change on Race and Ethnicity | Volume 6, Issue 1 | 2020

Dong, S., \& Lucas, M.S. (2016). An analysis of disability, academic performance, and seeking support in one university setting. Career Development and Transition for Exceptional Individuals, 39(1), 47-56. https://doi.org/10.1177/2165143413475658

Evans, N.J., Broido, E.M., Brown, K.R., \& Wilke, A.K. (2017). Disability in higher education: A social justice approach. John Wiley \& Sons.

Fleming, A.R., Oertle, K.M., \& Plotner, A.J. (2017). Student voices: Recommendations for improving postsecondary experiences of students with disabilities. Journal of Postsecondary Education and Disability, 30(4), 309-326.

Gelbar, N., Madaus, J.W., Dukes, L., Faggella-Luby, M., Volk, D., \& Monahan, J. (2019). Self-determination and college students with disabilities: Research trends and construct measurement. Journal of Student Affairs Research and Practice, 57(2), 1-19. https://doi.org/10.1080/19496591.2019.1631835

Getzel, E.E., \& Thoma, C.A. (2008). Experiences of college students with disabilities and the importance of self-determination in higher education settings. Career Development for Exceptional Individuals, 31(2), 77-84. https://doi.org/10.1177/0885728808317658

Ju, S., Zeng, W., Landmark, L.J. (2017). Self-determination and academic success of students with disabilities in postsecondary education: A review. Journal of Disability Policy Studies, 28(3), 180-189. https://doi.org/10.1177/1044207317739402

Kimball, E., Moore, A., Vaccarro, A., Troiano, P.F., \& Newman, B.M. (2016). College students with disabilities redefine activism: Self-advocacy, storytelling, and collective action. Journal of Diversity in Higher Education, 9(3), 245-260. https://doi.org/10.1037/dhe0000031

Koelsch, L.E. (2012). The virtual patchwork: A qualitative feminist research method. Qualitative Inquiry, 18(10), 823-829. https://doi.org/10.1177/1077800412456957

Ladson-Billings, G. (1998). Just what is critical race theory and what's it doing in a nice field like education? International Journal of Qualitative Studies in Education, 11(1), 7-24.

McCarthy, D. (2007). Teaching self-advocacy to students with disabilities. About Campus, 12(5), 10-16. https://doi.org/10.1080/095183998236863

Mingus, M. (2010, July 6). Reflecting on Frida Kahlo's birthday and the importance of recognizing ourselves for (in) each other [Blog post]. https://leavingevidence.wordpress.com/

Mingus, M. (2018, November 3). "Disability justice" is simply another term for love [Blog post]. https://leavingevidence.wordpress.com/

Petersen, A.J. (2009). "Ain't nobody gonna get me down": An examination of the educational experiences of four African-American women labeled with disabilities. Equity \& Excellence in Education, 42(4), 428-442. https://doi.org/10.1080/10665680903245284

Roberts, E.L., Ju, S., \& Zhang, D. (2016). Review of practices that promote selfadvocacy for students with disabilities. Journal of Disability Policy Studies, 26(4), 209-220. https://doi.org/10.1177/1044207314540213

Saldaña, J. (2009). The coding manual for qualitative researchers. Sage Publications. 
Journal Committed to Social Change on Race and Ethnicity | Volume 6, Issue 1 | 2020

Salinas Jr, C., \& Lozano, A. (2019). Mapping and recontextualizing the evolution of the term Latinx: An environmental scanning in higher education. Journal of Latinos and Education, 18(4), 302-315. https://doi.org/10.1080/15348431.2017.1390464

Scott, S. (2019). The AHEAD biennial survey of disability resource office structures and programs. Huntersville, NC: The Association on Higher Education and Disability.

Sievert, A.L., Cuvo, A.J., \& Davis, P.K. (1988). Training self-advocacy skills to adults with mild handicaps. Journal of Applied Behavior, 21(3), 299-309. https://doi.org/10.1901/jaba.1988.21-299

Stamp, L., Banerjee, M., \& Brown, F.C. (2014). Self-advocacy and perceptions of college readiness among students with ADHD. Journal of Postsecondary Education and Disability, 27(2), 209-223.

Test, D.W., Fowler, C.H., Wood, W.M., Brewer, D.M., \& Eddy, S. (2005). A conceptual framework of self-advocacy for students with disabilities. Remedial and Special Education, 26(1), 43-54. https://doi.org/10.1177/07419325050260010601

Tuck, E. \& Yang, K.W. (2014). Unbecoming claims: Pedagogies of refusal in qualitative research. Qualitative Inquiry, 20(6), 811-818. https://doi.org/10.1177/1077800414530265

Vaccaro, A. \& Kimball, E. (2017). "It's a very deep, layered topic": Student affairs professionals on the marginality and intersectionality of disability. In E. Kim \& K.C. Aquino (Eds.), Disability as diversity in higher education (pp. 138-152). Routledge.

Vaccaro, A., Moore, A., Kimball, E., Troiano, P.F., \& Newman, B.M. (2019). "Not gonna hold me back": Coping and resilience in students with disabilities. Journal of Student Affairs Research and Practice, 56(2), 181-193. https://doi.org/10.1080/19496591.2018.1506793

Walker, A.R., \& Test, D.W. (2011). Using a self-advocacy intervention on African American college students' ability to request academic accommodations. Learning Disabilities Research \& Practice, 26(3), 134-144. https://doi.org/10.1111/j.1540-5826.2011.00333.x 